\title{
ACTL6A Gene
}

National Cancer Institute

\section{Source}

National Cancer Institute. ACT L6A Gene. NCI Thesaurus. Code C157273.

This gene plays a role in transcriptional activation and repression of selected genes

through chromatin remodeling. 